\title{
Serological evidence of Rickettsia in horses from a semi- arid Brazilian region
}

\author{
Evidência sorológica de Rickettsia em cavalos da região semiárida do Brasil
}

Ila Ferreira Farias'; Eline Almeida Rodrigues de Souza1,2; Maria Carolina de Azevedo Serpa³; Flávio Silva Palha1; Glauber Meneses Barboza de Oliveira33; Marcelo Bahia Labruna3; Mauricio Claudio Horta1* (1)

\footnotetext{
${ }^{1}$ Laboratório de Doenças Parasitárias, Universidade Federal do Vale do São Francisco - UNIVASF, Petrolina, PE, Brasil ${ }_{2}^{2}$ Programa de Pós-graduação em Biociência Animal, Universidade Federal Rural de Pernambuco - UFRPE, Recife, PE, Brasil

${ }^{3}$ Departamento de Medicina Veterinária Preventiva e Saúde Animal, Faculdade de Medicina Veterinária e Zootecnia, Universidade de São Paulo - USP, São Paulo, SP, Brasil
}

How to cite: Farias IF, de Souza EAR, Serpa MAC, Palha FS, de Oliveira GMB, Labruna MB, et al. Serological evidence of Rickettsia in horses from a semi-arid Brazilian region. Braz J Vet Parasito/ 2021; 30(2): e026220. https://doi.org/10.1590/S1984-29612021011

\begin{abstract}
Brazilian spotted fever (BSF) is a common tick-borne disease caused by Rickettsia rickettsii. Horses are the primary hosts of the main vector, Amblyomma sculptum, and are considered efficient sentinels for circulation of Rickettsia. Therefore, the aim of this study was to detect antibodies reactive to $R$. rickettsii antigens in horses from a non-endemic area in the north-central region of Bahia state, Brazil. Blood samples and ticks were collected from 70 horses from the municipalities of Senhor do Bonfim, Antônio Gonçalves, Pindobaçu, and Campo Formoso. The sera obtained were tested by an indirect immunofluorescence assay to detect anti-Rickettsia antibodies. Overall, 5.7\% (4/70) of the horses reacted to R. rickettsii antigens. Ticks were collected from 18.6\% (13/70) of the horses and were identified as $A$. sculptum and Dermacentor nitens. Despite being a non-endemic area, seropositive animals were identified in our study, suggesting circulation of rickettsial agents in the region. This is the first serological survey of this agent in horses from the north-central region of Bahia, and further studies are needed to understand the epidemiology of BSF in these locations.
\end{abstract}

Keywords: Amblyomma sculptum, Brazilian spotted fever, rickettsiosis, horse.

\section{Resumo}

A Febre Maculosa Brasileira (FMB) é uma importante zoonose causada por Rickettsia rickettsii, sendo seu vetor - Amblyomma sculptum. Cavalos são os principais hospedeiros desse carrapato e considerados sentinelas eficientes para detectar a circulação de Rickettsia. O objetivo deste estudo foi detectar anticorpos reativos a antígenos de $R$. rickettsii em cavalos de uma área não-endêmica na região Centro-Norte da Bahia, Brasil. Foram coletadas amostras de sangue e carrapatos de 70 cavalos nos municípios de Senhor do Bonfim, Antônio Gonçalves, Pindobaçu e Campo Formoso. Os soros obtidos foram testados pela reação de imunofluorescência indireta para detectar anticorpos anti-Rickettsia. No geral, 5,7\% (4/70) dos cavalos reagiram sorologicamente para antígenos de $R$. rickettsii. Os carrapatos foram coletados em 18,6\% (13/70) dos cavalos e foram identificados como A. sculptum e Dermacentor nitens. Embora seja uma área não endêmica, foram observados animais soropositivos, sugerindo a circulação de riquétsias na região estudada. Este é o primeiro estudo de levantamento sorológico desse agente em cavalos do Centro-Norte da Bahia. São necessários mais estudos para compreender a epidemiologia da FMB nesses locais.

Palavras-chave: Amblyomma sculptum, febre maculosa brasileira, riquetsioses, cavalo. 
Brazilian spotted fever (BSF) is a common tick-borne disease caused by the bacterium Rickettsia rickettsii and is considered the most important rickettsial disease in Brazil due to $>50 \%$ fatality rates (Luz et al., 2019). This disease is endemic in areas of the Atlantic Forest biome in southeastern and southern Brazil (Moraes-Filho et al., 2009). The Brazilian territory has adopted a compulsory notification for BSF since 2001 (Ordinance $\mathrm{N}^{\circ} .1,943$ of 18/10/2001) due to its growing prevalence (Brasil, 2001). The Notifiable Diseases Information System (SINAN) confirmed 2,127 cases of BSF between 2007 and 2019. The southeastern region, especially the state of São Paulo, has the maximum number of cases $(n=1,555)$, followed by the southern region with 520 confirmed cases. In addition to BSF, cases of a mild spotted fever caused by the bacterium Rickettsia parkeri have also been reported in humans in different areas of the Atlantic Forest biome. This condition has been reported in the northeastern region in addition to the southeastern and southern regions of the country (da Paixão Sevá et al., 2019).

Areas in the northeast are considered non-endemic for BSF, possibly due to the lack of suspicion or diagnosis (Oliveira, 2016). However, infection caused by R. parkeri in the Atlantic Forest has been confirmed among humans in the state of Bahia in the municipality of Ilhéus (da Paixão Sevá et al., 2019), Chapada Diamantina National Park (Silva et al., 2011), and in the state of Ceará in the municipalities of Aratuba, Baturité, Guaramiranga, and Pacoti (Oliveira, 2016). In the endemic area of Ilhéus, seroreactivity of dogs and horses for spotted fever group rickettsiae have also been reported (Oliveira et al., 2019).

The vectors of BSF are ticks of the species Amblyomma aureolatum, identified only in the São Paulo metropolitan region, and Amblyomma sculptum, which is responsible for transmitting the highest number of cases. A. sculptum is the most common human-biting tick in Brazil and the main vector of $R$. rickettsii, and is distributed mainly in the Cerrado and Pantanal biomes and in degraded areas of the Atlantic Forest biome (Moraes-Filho et al., 2009). In contrast, there are limited records of the presence of $A$. sculptum in the Caatinga biome, for example, in the north-central region of Bahia state, which represents a narrow invagination of the tropical climate (Martins et al., 2016). However, there is no information regarding tick-borne rickettsiae in this remote region.

Horses and capybaras are among the most common hosts for all parasitic stages of $A$. sculptum, especially in human-modified landscapes (Luz et al., 2019). Horses do not play a direct role in the epidemiology of BSF, since they do not develop rickettsemia or serve as a source of $R$. rickettsii for ticks (Ueno et al., 2016). On the other hand, horses elicit an effective humoral response on exposure to $R$. rickettsii-infected ticks; therefore, horses are considered suitable sentinels for epidemiological surveillance of BSF (Ueno et al., 2016).

BSF can be confused with other febrile and exanthematic diseases in humans (Traeger et al., 2015). Owing to the scarcity of studies, knowledge of the circulation of spotted fever group (SFG) rickettsiae in the northeastern region of Brazil is of great importance, especially where the tick vector has already been identified. Thus, the aim of this study was to assess the prevalence of anti-Rickettsia antibodies in horses in a BSF-non-endemic area within the semi-arid Caatinga biome, where the presence of A. sculptum was previously reported by Martins et al. (2016).

This study was approved by the Committee on Ethics in the Use of Animals (CEUA) under protocol no. 0004/180418. It was carried out in the microregion of Senhor do Bonfim, located in the north-central area of the state of Bahia, Northeastern Brazil, composed of nine municipalities, four of which were included in this

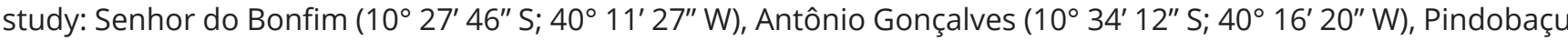

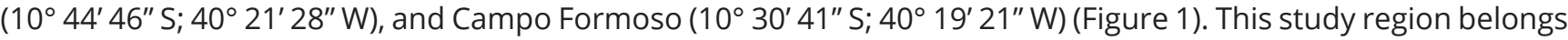
to the Caatinga biome; however, this area has tropical climate in contrast to the general semi-arid climate in the biome (Martins et al., 2016).

Blood was collected from 70 horses selected according to convenience, aged between 9 and 180 months old, from May 2017 to July 2017, based on the availability of rural owners in the region. After physically restraining the animals, blood samples were collected from the jugular vein after disinfection with $70 \%$ alcohol, by using a $25 \mathrm{~mm} \times 8 \mathrm{~mm}$ sterile needle. Blood samples were stored in sterile glass tubes without anticoagulant at room temperature. After clot retraction (two to six hours), the samples were centrifuged at 5,000 $\mathrm{g}$ for 15 minutes to obtain sera, which were stored at $-20^{\circ} \mathrm{C}$ until laboratory analysis.

Horse sera were tested for the presence of antibodies reactive to SFG rickettsiae by the indirect immunofluorescence assay, with $R$. rickettsii crude antigens as described in previous studies (Horta et al., 2007). Briefly, R. rickettsii strain Taiaçu was grown in Vero cells and harvested when nearly $100 \%$ of the cells were infected. The infected cells were centrifuged at $12,000 \mathrm{~g}$ for 10 minutes and the pellet was washed in $0.1 \mathrm{M}$ phosphatebuffered saline (PBS, pH 7.4), centrifuged again, and resuspended in PBS containing $1 \%$ bovine calf serum (Sigma, St Louis, USA), and $0.1 \%$ sodium azide (Sigma, St Louis, USA). Ten microliters ( $\approx 500$ rickettsiae-infected cells) were applied onto each well of 12-well slides. The antigens on the slides were air-dried and then fixed in acetone for 


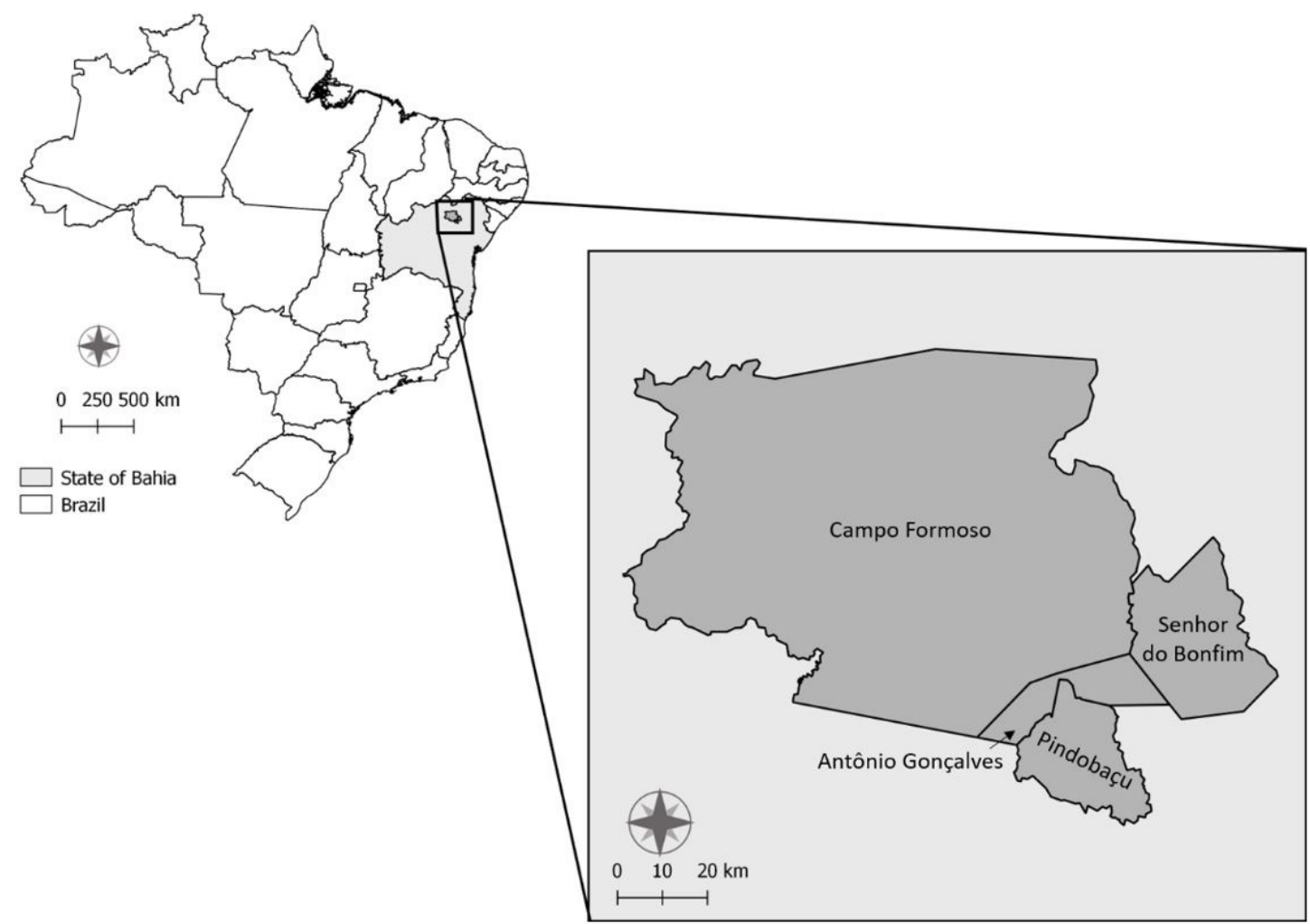

Figure 1. Municipalities of Antônio Gonçalves, Campo Formoso, Pindobaçu, and Senhor do Bonfim located in the north-central area of the state of Bahia, Brazil.

10 minutes. Slides were kept at $-20^{\circ} \mathrm{C}$ until used. All procedures of antigen preparation were performed within a class II biosafety cabinet.

Horse sera were diluted in twofold increments with PBS starting from the 1:64 dilution. Ten microliters of diluted sera were added to each well of the antigen slides. The slides were incubated at $37^{\circ} \mathrm{C}$ for 30 minutes in a humidity box. The slides were rinsed once, then washed twice for 10 minutes per wash in PBS. The slides were incubated with fluorescein isothiocyanate-labeled goat anti-horse IgG (Sigma, St Louis, USA), and then mounted with buffered glycerin under coverslips. The slides were read using an ultraviolet microscope (Olympus, Tokyo, Japan) at 400x magnification. Serum was considered to contain antibodies against the rickettsiae if it displayed a reaction at the 1:64 dilution; however, sera reactive at this dilution were titrated to determine the endpoint titer.

Sampled horses were also examined for the presence of ticks, which were collected and stored in microtubes containing holes in the lid to maintain viability. Taxonomic identification of the adult ticks was performed according to Nava et al. (2014). At the time of sample collection, horse owners answered a questionnaire with information about the horses, such as sex, functionality (sports activities, walking, and/or work), the environment in which they lived, and the type of breeding. Breeding was classified as extensive, semi-extensive, and intensive systems. In the extensive breeding system, horses were reared in native fields with access to forest areas and streams, where they were potentially in contact with wild animals (such as marsupials, rodents, carnivores). In semi-intensive breeding, the animals spent one part of the day in stalls and the other in native fields. In the intensive system, the animals were always in the stall, with no access to native fields.

A total of 70 horses were evaluated (21 females and 49 males), from the municipalities of Antônio Gonçalves (8), Campo Formoso (49), Pindobaçu (7), and Senhor do Bonfim (6). Anti-Rickettsia reactive antibodies were detected in 5.7\% (4/70) of the sampled horses, with endpoint titers varying from 128 to 2,048 (Table 1). Of these, two horses belonged to the Pindobaçu and two to the Campo Formoso municipalities. These four seropositive horses were three males and one female, aged between 48 and 144 months old, and were bred extensively for varied purposes (sports, reproduction, and walking), and did not have history of travelling to other municipalities. Although ticks were not seen on any of the seropositive horses, owners reported that all horses had already presented ticks at some moment in their lives. 
Table 1. Number of seroreactive horses to Rickettsia and the number of ticks collected from the horses, according to the municipalities in the state of Bahia, Brazil.

\begin{tabular}{ccccc}
\hline \multirow{2}{*}{ Municipalities } & $\begin{array}{c}\text { Seroreactive horses } \\
(\%)\end{array}$ & Tested horses & Amblyomma sculptum & Dermacentor nitens \\
\hline Antônio Gonçalves & $0(0)$ & 8 & 1 & 3 \\
Campo Formoso & $2(4.1)$ & 49 & 102 & 18 \\
Pindobaçu & $2(28.6)$ & 7 & 0 & 0 \\
Senhor do Bonfim & $0(0)$ & 6 & 0 & 0 \\
Total & $4(5.5)$ & 72 & 103 & 21 \\
\hline
\end{tabular}

The horses sampled in the present study were bred in extensive or semi-extensive systems. Thus, the animals potentially had contact with other animals as well as access to forest areas and streams. Rickettsia-infected ticks from wildlife could infest domestic animals that have access to forest areas or share the same environment as wild fauna (i.e., rodents, marsupials, carnivores). This could be related to their serological status, as reported for seropositive horses in other regions (Medeiros et al., 2013).

At the time of the evaluation, tick infestation was observed in $18.6 \%(13 / 70)$ of the horses, $15.4 \%(2 / 13)$ in the municipality of Antônio Gonçalves and 84.6\% (11/13) in the municipality of Campo Formoso (Table 1). Of the total adult ticks collected, 83\% (103/124) were identified as A. sculptum and 17\% (21/124) as Dermacentor nitens. Although A. sculptum is endemic to the Cerrado and Atlantic Forest biomes, its presence in the Caatinga biome may be related to a narrow invagination of the tropical climate in this biome, where it was first reported (Martins et al., 2016).

The present study demonstrated, for the first time, the presence of anti-Rickettsia antibodies in horses from the Caatinga biome, in an area in the state of Bahia where spotted fever has never been reported. These findings suggest the exposure of horses to this microorganism, especially because the seropositive animals did not have a travel history to other locations. Moreover, one animal had a high endpoint titer $(2,048)$, suggesting recent exposure to rickettsiae (Ueno et al., 2016; Guimarães et al., 2017). Furthermore, we clearly demonstrated the reactivity of horse sera to $R$. rickettsii antigens. These results must be interpreted as evidence of exposure to rickettsial agents, since it has been shown that $R$. rickettsii-infected horses demonstrate serum reactivity to different Rickettsia species (Ueno et al. 2016) by antigen cross-reactions among members of this bacterial group. Further studies employing methods of direct diagnosis of rickettsiae (i.e., isolation, molecular detection) are warranted to confirm the circulation of SFG rickettsiae in the study region.

Considering that this is the first study to evaluate rickettsial exposure in horses from the Caatinga biome, we could not identify the exact Rickettsia species that elicited the antibody response to the $R$. rickettsii antigens. However, among the two tick species found on horses, $D$. nitens and A. sculptum, only the latter has been reported to be infected by SFG rickettsiae in Brazil. In fact, $A$. sculptum is the main vector of $R$. rickettsii in humans in southeastern Brazil (Gerardi et al., 2019), although this tick has rarely been found to harbor DNA of other SFG agents, such as Rickettsia amblyommatis (Barbieri et al., 2019), Rickettsia bellii (Machado et al., 2018), and 'Candidatus Rickettsia andeanae' (Witter et al., 2016). In addition, another tick species known to occur throughout the Caatinga biome, $A$. auricularium, has been found to be infected by $R$. amblyommatis in other Caatinga areas in the state of Bahia (Lugarini et al., 2015; Maia et al., 2018). Therefore, further studies are needed to identify the exact Rickettsia species that possibly infected the horses in the areas sampled in the present study.

Horses are considered suitable sentinels because they develop an efficient and long-lasting humoral response after infection by SFG rickettsiae (Horta et al., 2007; Ueno et al., 2016). The present study suggested the presence of rickettsial species in a BSF-non-endemic area in the north-central region of Bahia. To date, the risk of the disease becoming endemic in this region is low. Nevertheless, the results of this study are fundamental for increasing knowledge about the risks of the disease and the occurrence of rickettsial agents in the semi-arid Caatinga biome.

\section{Acknowledgments}

MBL and MCH are recipients of research fellowships from CNPq (grant number: 301641/2019-6 and 308668/20189, respectively). 


\section{References}

Barbieri ARM, Szabó MPJ, Costa FB, Martins TF, Soares HS, Pascoli G, et al. Species richness and seasonal dynamics of ticks with notes on rickettsial infection in a Natural Park of the Cerrado biome in Brazil. Ticks Tick Borne Dis 2019; 10(2): 442-453. http:// dx.doi.org/10.1016/j.ttbdis.2018.12.010. PMid:30611725.

Brasil. Ministério da Saúde. Portaria n 1.943, de 18 de outubro de 2001, sobre doenças de notificação compulsória. Define a relação de doenças de notificação compulsória para todo território nacional. Inf Epidemiol Sus 2001; 10(1): 57-58. http://dx.doi. org/10.5123/S0104-16732001000100007.

da Paixão Sevá A, Martins TF, Muñoz-Leal S, Rodrigues AC, Pinter A, Luz HR, et al. A human case of spotted fever caused by Rickettsia parkeri strain Atlantic rainforest and its association to the tick Amblyomma ovale. Parasit Vectors 2019; 12(1): 471. http:// dx.doi.org/10.1186/s13071-019-3730-2. PMid:31604442.

Gerardi M, Ramírez-Hernández A, Binder LC, Krawczak FS, Gregori F, Labruna MB. Comparative susceptibility of different populations of Amblyomma sculptum to Rickettsia rickettsii. Front Physio/ 2019; 10: 653. http://dx.doi.org/10.3389/fphys.2019.00653. PMid:31191350.

Guimarães MF, Araujo AC, Freire DP, Machado DMR, Martins NNVM, Moraes-Filho J, et al. Investigação sorológica de Rickettsia rickettsii e Coxiella burnetii em caprinos e ovinos no entorno do Parque Nacional da Serra das Confusões, Piauí. Pesq Vet Bras 2017; 37(6): 555-560. http://dx.doi.org/10.1590/s0100-736x2017000600004.

Horta MC, Labruna MB, Pinter A, Linardi PM, Schumaker TTS. Rickettsia infection in five areas of the state of São Paulo, Brazil. Mem Inst Oswaldo Cruz 2007; 102(7): 793-801. http://dx.doi.org/10.1590/S0074-02762007000700003. PMid:18094887.

Lugarini C, Martins TF, Ogrzewalska M, de Vasconcelos NC, Ellis VA, de Oliveira JB, et al. Rickettsial agents in avian ixodid ticks in northeast Brazil. Ticks Tick Borne Dis 2015; 6(3): 364-375. http://dx.doi.org/10.1016/j.ttbdis.2015.02.011. PMid:25800099.

Luz HR, Costa FB, Benatti HR, Ramos VN, de A. Serpa MC, Martins TF, et al. Epidemiology of capybara-associated Brazilian spotted fever. PLoS Neg/ Trop Dis 2019; 13(9): e0007734. http://dx.doi.org/10.1371/journal.pntd.0007734. PMid:31490924.

Machado IB, Bitencourth K, Cardoso KM, Oliveira SV, Santalucia M, Marques SFF, et al. Diversity of rickettsiae and potential vectors of spotted fever in an area of epidemiological interest in the Cerrado biome, midwestern Brazil. Med Vet Entomol 2018; 32(4): 481-489. http://dx.doi.org/10.1111/mve.12315. PMid:29972600.

Maia MO, Koppe VC, Muñoz-Leal S, Martins TF, Marcili A, Labruna M, et al. Detection of Rickettsia spp. in ticks associated to wild mammals in Northeastern Brazil, with notes on an undetermined Ornithodoros sp. collected from marsupials. Exp Appl Acarol 2018; 76(4): 523-535. http://dx.doi.org/10.1007/s10493-018-0323-2. PMid:30443697.

Martins TF, Barbieri ARM, Costa FB, Terassini FA, Camargo LMA, Peterka CRL, et al. Geographical distribution of Amblyomma cajennense (sensu latu) ticks (Parasitiformes: Ixodidae) in Brazil, with description of the nymph of $A$. cajennense (sensu stricto). Parasit Vectors 2016; 9(1): 186. http://dx.doi.org/10.1186/s13071-016-1460-2. PMid:27036324.

Medeiros AP, Moura AB, Souza AP, Bellato V, Sartor AA, Vieira-Neto A, et al. Antibodies against rickettsiae from spotted fever groups in horses from two mesoregions in the state of Santa Catarina, Brazil. Arq Bras Med Vet Zootec 2013; 65(6): $1713-1719$. http://dx.doi.org/10.1590/S0102-09352013000600019.

Moraes-Filho J, Horta MC, Pacheco RC, Maeda MM, Galano A, Oliveira ML, et al. Pesquisa de anticorpos anti-Rickettsia rickettsii em equinos do Centro de Controle de Zoonoses do município de São Paulo (CCZ/SP). Braz J Vet Res Anim Sci 2009; 46(2): 85-91. http://dx.doi.org/10.11606/issn.1678-4456.bjvras.2009.26753.

Nava S, Beati L, Labruna MB, Cáceres AG, Mangold AJ, Guglielmone AA. Reassessment of the taxonomic status of Amblyomma cajennense (Fabricius, 1787) with the description of three new species, Amblyomma tonelliae n. sp., Amblyomma interandinum n. sp. and Amblyomma patinoi n. sp., and reinstatement of Amblyomma mixtum Koch, 1844, and Amblyomma sculptum Berlese, 1888 (Ixodida: ixodidae). Ticks Tick Borne Dis 2014; 5(3): 252-276. http://dx.doi.org/10.1016/j.ttbdis.2013.11.004. PMid:24556273.

Oliveira PB, Harvey TV, Fehlberg HF, Rocha JM, Martins TF, Acosta ICL, et al. Serologic and molecular survey of Rickettsia spp. in dogs, horses and ticks from the Atlantic rainforest of the state of Bahia, Brazil. Exp Appl Acarol 2019; 78: 431-442. https://doi. org/10.1007/s10493-019-00397-x.

Oliveira SV. Tick-borne spotted fever in the northeast of Brazil: the series of cases a new endemic area. Rev Med UFC 2016; 56(2): 8-9. http://dx.doi.org/10.20513/2447-6595.2016v56n2p8-9.

Silva N, Eremeeva ME, Rozental T, Ribeiro GS, Paddock CD, Ramos EAG, et al. Eschar-associated Spotted Fever Rickettsiosis, Bahia, Brazil. Emerg Infect Dis 2011; 17(2): 275-278. http://dx.doi.org/10.3201/eid1702.100859. PMid:21291605.

Traeger MS, Regan JJ, Humpherys D, Mahoney DG, Martinez M, Emerson GG, et al. Rocky Mountain spotted fever characterization and comparison to similar illnesses in a highly endemic area-Arizona, 2002-2011. Clin Infect Dis 2015; 60(11): 1650-1658. http:// dx.doi.org/10.1093/cid/civ115. PMid:25697743.

Ueno TE, Costa FB, Moraes-Filho J, Agostinho WC, Fernandes WR, Labruna MB. Experimental infection of horses with Rickettsia rickettsii. Parasit Vectors 2016; 9(1): 499. http://dx.doi.org/10.1186/s13071-016-1784-y. PMid:27624315.

Witter R, Martins TF, Campos AK, Melo ALT, Corrêa SHR, Morgado TO, et al. Rickettsial infection in ticks (Acari: Ixodidae) of wild animals in midwestern Brazil. Ticks Tick Borne Dis 2016; 7(3): 415-423. http://dx.doi.org/10.1016/j.ttbdis.2015.12.019. PMid:26775021. 